\title{
What Do We Know (And Not Know) About Potential Output?
}

\author{
Susanto Basu and John G. Fernald
}

\begin{abstract}
Potential output is an important concept in economics. Policymakers often use a one-sector neoclassical model to think about long-run growth, and they often assume that potential output is a smooth series in the short run-approximated by a medium- or long-run estimate. But in both the short and the long run, the one-sector model falls short empirically, reflecting the importance of rapid technological change in producing investment goods; and few, if any, modern macroeconomic models would imply that, at business cycle frequencies, potential output is a smooth series. Discussing these points allows the authors to discuss a range of other issues that are less well understood and where further research could be valuable. (JEL E32, O41, E60)
\end{abstract}

Federal Reserve Bank of St. Louis Review, July/August 2009, 91(4), pp. 187-213.

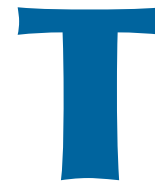
he concept of potential output plays a central role in policy discussions. In the long run, faster growth in potential output leads to faster growth in actual output and, for given trends in population and the workforce, faster growth in income per capita. In the short run, policymakers need to assess the degree to which fluctuations in observed output reflect the economy's optimal response to shocks, as opposed to undesirable deviations from the time-varying optimal path of output.

To keep the discussion manageable, we confine our discussion of potential output to neoclassical growth models with exogenous technical progress in the short and the long run; we also focus exclusively on the United States. We make two main points. First, in both the short and the long run, rapid technological change in producing equipment investment goods is important. This rapid change in the production technology for investment goods implies that the two-sector neoclassical model-where one sector produces investment goods and the other produces consumption goods-provides a better benchmark for measuring potential output than the one-sector growth model. Second, in the short run, the measure of potential output that matters for policymakers is likely to fluctuate substantially over time. Neither macroeconomic theory nor existing empirical evidence suggests that potential output is a smooth series. Policymakers, however, often appear to assume that, even in the short run, potential output is well approximated by a smooth trend. ${ }^{1}$ Our model and empirical work corroborate these two points and provide a framework to discuss other aspects of what we know, and do not know, about potential output.

As we begin, clear definitions are important to our discussion. "Potential output" is often used

\footnotetext{
1 See, for example, Congressional Budget Office (CBO, 2001 and 2004) and Organisation for Economic Co-operation and Development (2008).
} 
to describe related, but logically distinct, concepts. First, people often mean something akin to a "forecast" for output and its growth rate in the longer run (say, 10 years out). We will often refer to this first concept as a "steady-state measure," although a decade-long forecast can also incorporate transition dynamics toward the steady state. ${ }^{2}$

In the short run, however, a steady-state notion is less relevant for policymakers who wish to stabilize output or inflation at high frequencies. This leads to a second concept, explicit in New Keynesian dynamic stochastic general equilibrium (DSGE) models: Potential output is the rate of output the economy would have if there were no nominal rigidities but all other (real) frictions and shocks remained unchanged. ${ }^{3}$ In a flexible price real business cycle model, where prices adjust instantaneously, potential output is equivalent to actual, equilibrium output. In contrast to the first definition of potential output as exclusively a long-term phenomenon, the second meaning defines it as relevant for the short run as well, when shocks push the economy temporarily away from steady state.

In New Keynesian models, where prices and/or wages might adjust slowly toward their long-run equilibrium values, actual output might well deviate from the short-term measure of potential output. In many of these models, the "output gap"- - the difference between actual and potential output-is the key variable in determining the evolution of inflation. Thus, this second definition also corresponds to the older Keynesian notion that potential output is the "maximum production without inflationary pressure" (Okun, 1970, p. 133) - that is, the level of output at which there is no pressure for inflation to either increase or decrease. In most, if not all, macroeconomic models, the second (flexible price) definition converges in the long run to the first steady-state definition.

\footnotetext{
2 In some models, transition dynamics can be very long-lived. For example, Jones (2002) interprets the past century as a time when growth in output per capita was relatively constant at a rate above steady state.

3 See Woodford (2003) for the theory. Neiss and Nelson (2005) construct an output gap from a small, one-sector DSGE model.
}

Yet a third definition considers potential output as the current optimal rate of output. With distortionary taxes and other market imperfections (such as monopolistic competition), neither steady-state output nor the flexible price equilibrium level of output needs to be optimal or efficient. Like the first two concepts, this third meaning is of interest to policymakers who might seek to improve the efficiency of the economy. ${ }^{4}$ (However, decades of research on time inconsistency suggest that such policies should be implemented by fiscal or regulatory authorities, who can target the imperfections directly, but not by the central bank, which typically must take these imperfections as given. See, for example, the seminal paper by Kydland and Prescott, 1977.)

This article focuses on the first two definitions. The first part of our article focuses on long-term growth, which is clearly an issue of great importance for the economy, especially in discussions of fiscal policy. For example, whether promised entitlement spending is feasible depends almost entirely on long-run growth. We show that the predictions of two-sector models lead us to be more optimistic about the economy's long-run growth potential. This part of our article, which corresponds to the first definition of potential output, will thus be of interest to fiscal policymakers.

The second part of our article, of interest to monetary policymakers, focuses on a time-varying measure of potential output-the second usage above. Potential output plays a central, if often implicit, role in monetary policy decisions. The Federal Reserve has a dual mandate to pursue low and stable inflation and maximum sustainable employment. "Maximum sustainable employment" is usually interpreted to imply that the Federal Reserve should strive, subject to its other mandate, to stabilize the real economy around its flexible price equilibrium level—which itself is changing in response to real shocks-to avoid inefficient fluctuations in employment. In New Keynesian models, deviations of actual from potential output put pressure on inflation, so in

\footnotetext{
4 Justiniano and Primiceri (2008) define "potential output" as this third measure, with no market imperfections; they use the term "natural output" to mean our second, flexible-wage/price measure.
} 
the simplest such models, output stabilization and inflation stabilization go hand in hand.

The first section of this article compares the steady-state implications of one- and two-sector neoclassical models with exogenous technological progress. That is, we focus on the long-run effects of given trends in technology, rather than trying to understand the sources of this technological progress. ${ }^{5}$ Policymakers must understand the nature of technological progress to devise policies to promote long-run growth, but it is beyond the scope of our article. In the next section, we use the two-sector model to present a range of possible scenarios for long-term productivity growth and discuss some of the questions these different scenarios pose.

We then turn to short-term implications and ask whether it is plausible to think of potential output as a smooth process and compare the implications of a simple one-sector versus twosector model. The subsequent section turns to the current situation (as of late 2008): How does short-run potential output growth compare with its steady-state level? This discussion suggests a number of additional issues that are unknown or difficult to quantify. The final section summarizes our findings and conclusions.

\section{THE LONG RUN: WHAT SIMPLE MODEL MATCHES THE DATA?}

A common, and fairly sensible, approach for estimating steady-state output growth is to estimate growth in full-employment labor productivity and then allow for demographics to determine the evolution of the labor force. This approach motivates this section's assessment of steadystate labor productivity growth.

We generally think that, in the long run, different forces explain labor productivity and total hours worked-technology along with induced

\footnotetext{
5 Of course, total factor productivity (TFP) can change for reasons broader than technological change alone; improved institutions, deregulation, and less distortionary taxes are only some of the reasons. We believe, however, that long-run trends in TFP in developed countries like the United States are driven primarily by technological change. For evidence supporting this view, see Basu and Fernald (2002).
}

capital deepening explains the former and demographics explains the latter. The assumption that labor productivity evolves separately from hours worked is motivated by the observation that labor productivity has risen dramatically over the past two centuries, whereas labor supply has changed by much less. ${ }^{6}$ Even if productivity growth and labor supply are related in the long run, as suggested by Elsby and Shapiro (2008) and Jones (1995), the analysis that follows will capture the key properties of the endogenous response of capital deepening to technological change.

A reasonable way to estimate steady-state labor productivity growth is to estimate underlying technology growth and then use a model to calculate the implications for capital deepening. Let hats over a variable represent log changes. As a matter of identities, we can write output growth, $\hat{y}$, as labor-productivity growth plus growth in hours worked, $\hat{h}$ :

$$
\hat{y}=(\hat{y}-\hat{h})+\hat{h}
$$

We focus here on full-employment labor productivity.

Suppose we define growth in total factor productivity (TFP), or the Solow residual, as

$$
\widehat{t f p}=\hat{y}-\alpha \hat{k}-(1-\alpha) \hat{l},
$$

where $\alpha$ is capital's share of income and $(1-\alpha)$ is labor's share of income. Defining

$$
\hat{l} \equiv \hat{h}+\widehat{l q},
$$

where $\widehat{I q}$ is labor "quality" (composition) growth, ${ }^{7}$ we can rewrite output per hour growth as follows:

$$
(\hat{y}-\hat{h})=\widehat{t f p}+\alpha(\hat{k}-\hat{l})+\widehat{l q}
$$

As an identity, growth in output per hour worked reflects TFP growth; the contribution of

\footnotetext{
6 King, Plosser, and Rebelo (1988) suggest a first approximation should model hours per capita as independent of the level of technology and provide necessary and sufficient conditions on the utility function for this result to hold. Basu and Kimball (2002) show that the particular non-separability between consumption and hours worked that is generally implied by the King-PlosserRebelo utility function helps explain the evolution of consumption in postwar U.S. data and resolves several consumption puzzles.

7 See footnote 7 on p. 190.
} 
capital deepening, defined as $\alpha(\hat{k}-\hat{l})$; and increases in labor quality. Economic models suggest mappings between fundamentals and the terms in this identity that are sometimes trivial and sometimes not.

\section{The One-Sector Model}

Perhaps the simplest model that could reasonably be applied to the long-run data is the onesector neoclassical growth model. Technological progress and labor force growth are exogenous and capital deepening is endogenous.

We can derive the key implications from the textbook Solow version of the model. Consider an aggregate production function $Y=K^{\alpha}(A L)^{1-\alpha}$, where technology $A$ grows at rate $g$ and labor input $L$ (which captures both raw hours, $H$, and labor quality, $L Q$ - henceforth, we do not generally differentiate between the two) grows at rate $n$. Expressing all variables in terms of "effective labor," $A L$, yields

$$
y=k^{\alpha}
$$

where $y=Y / A L$ and $k=K / A L$.

Capital accumulation takes place according to the perpetual-inventory formula. If $s$ is the saving rate, so that $s y$ is investment per effective worker, then in steady state

$$
s y=(n+\delta+g) k \text {. }
$$

Because of diminishing returns to capital, the economy converges to a steady state where $y$ and $k$ are constant. At that point, investment per effective worker is just enough to offset the effects of

7 Labor quality/composition reflects the mix of hours across workers with different levels of education, experience, and so forth. For the purposes of this discussion, which so far has focused on definitions, suppose there were $J$ types of workers with factor shares of income $\beta_{j}$, where

$$
\sum_{j} \beta_{j}=(1-\alpha)
$$

Then a reasonable definition of TFP would be

$$
\widehat{t f p}=\hat{y}-\alpha \hat{k}-\sum_{j} \beta_{j} \hat{h}_{j} .
$$

Growth accounting as done by the Bureau of Labor Statistics or by Dale Jorgenson and his collaborators (see, for example, Jorgenson, Gollop, and Fraumeni, 1987) defines

$$
\hat{l}=\sum_{j} \beta_{j} \hat{h}_{j} /(1-\alpha), \hat{h}=d \ln \sum_{j} H_{j} \text {, and } \hat{q}=\hat{l}-\hat{h} .
$$

depreciation, population growth, and technological change on capital per effective worker. In steady state, the unscaled levels of $Y$ and $K$ grow at the rate $g+n$; capital deepening, $K / L$, grows at rate $g$. Labor productivity $Y / L$ (i.e., output per unit of labor input) also grows at rate $g$.

From the production function, measured TFP growth is related to labor-augmenting technology growth by

$$
\widehat{t f p}=\hat{Y}-\alpha \hat{K}-(1-\alpha) \hat{L}=(1-\alpha) g .
$$

The model maps directly to equation (1). In particular, the endogenous contribution of capital deepening to labor-productivity growth is

$$
\alpha g=\alpha \cdot \widehat{t f p} /(1-\alpha) .
$$

Output per unit of labor input grows at rate $g$, which equals the sum of standard TFP growth, $(1-\alpha) g$, and induced capital deepening, $\alpha g$.

Table 1 shows how this model performs relative to the data. It uses the multifactor productivity release from the Bureau of Labor Statistics (BLS), which provides data for TFP growth as well as capital deepening for the U.S. business economy. These data are shown in the first two columns. Note that in the model above, standard TFP growth reflects technology alone. In practice, a large segment of the literature suggests reasons why nontechnological factors might affect measured TFP growth. For example, there are hardto-measure short-run movements in labor effort and capital's workweek, which cause measured (although not actual) TFP to fluctuate in the short run. Nonconstant returns to scale and markups also interfere with the mapping from technological change to measured aggregate TFP. But the deviations between technology and measured TFP are likely to be more important in the short run than in the long run, consistent with the findings of Basu, Fernald, and Kimball (2006) and Basu et al. (2008). Hence, for these longer-term comparisons, we assume average TFP growth reflects average technology growth. Column 3 shows the predictions of the one-sector neoclassical model for $\alpha=0.32$ (the average value in the BLS multifactor dataset). 


\section{Table 1}

\section{One-Sector Growth Model Predictions for the U.S. Business Sector}

\begin{tabular}{lccc} 
Period & Total TFP & $\begin{array}{c}\text { Predicted capital } \\
\text { Actual capital } \\
\text { deepening contribution }\end{array}$ & $\begin{array}{c}\text { deepening contribution } \\
\text { in one-sector model }\end{array}$ \\
\hline $1948-2007$ & 1.39 & 0.76 & 0.65 \\
$1948-1973$ & 2.17 & 0.85 & 1.02 \\
$1973-1995$ & 0.52 & 0.62 & 0.25 \\
$1995-2007$ & 1.34 & 0.84 & 0.63 \\
$1995-2000$ & 1.29 & 1.01 & 0.61 \\
$2000-2007$ & 1.37 & 0.72 & 0.65
\end{tabular}

NOTE: Data for columns 1 and 2 are business sector estimates from the BLS multifactor productivity database (downloaded via Haver on August 19, 2008). Capital and labor are adjusted for changes in composition. Actual capital deepening is $\alpha(\hat{k}-\hat{l})$, and predicted capital deepening is $\alpha \cdot \widehat{t f p} /(1-\alpha)$.

A comparison of columns 2 and 3 shows the model does not perform particularly well. It slightly underestimates the contribution of capital deepening over the entire 1948-2007 period, but it does a particularly poor job of matching the lowfrequency variation in that contribution. In particular, it somewhat overpredicts capital deepening for the pre-1973 period but substantially underpredicts for the 1973-95 period. That is, given the slowdown in TFP growth, the model predicts a much larger slowdown in the contribution of capital deepening. ${ }^{8}$

One way to visualize the problem with the one-sector model is to observe that the model predicts a constant capital-to-output ratio in steady state-in contrast to the data. Figure 1 shows the sharp rise in the business sector capital-to-output ratio since the mid-1960s.

\section{The Two-Sector Model: A Better Match}

A growing literature on investment-specific technical change suggests an easy fix for this

8 Note that output per unit of quality-adjusted labor is the sum of TFP plus the capital deepening contribution, which in the business sector averaged $1.39+0.76=2.15$ percent per year over the full sample. More commonly, labor productivity is reported as output per hour worked. Over the sample, labor quality in the BLS multifactor productivity dataset rose 0.36 percent per year, so output per hour rose 2.51 percent per year. failure: Capital deepening does not depend on overall TFP but on TFP in the investment sector. A key motivation for this body of literature is the price of business investment goods, especially equipment and software, relative to the price of other goods (such as consumption). The relative price of investment and its main components are shown in Figure 2.

Why do we see this steady relative price decline? The most natural interpretation is that there is a more rapid pace of technological change in producing investment goods (especially hightech equipment). ${ }^{9}$

To realize the implications of a two-sector model, consider a simple two-sector Solow-type model, where $s$ is the share of nominal output that is invested each period. ${ }^{10}$ One sector produces investment goods, $I$, that are used to create capital; the other sector produces consumption goods, $C$. The two sectors use the same Cobb-Douglas production function but with potentially different technology levels:

9 On the growth accounting side, see, for example, Jorgenson (2001) or Oliner and Sichel (2000); see also Greenwood, Hercowitz, and Krusell (1997).

${ }^{10}$ This model is a fixed-saving rate version of the two-sector neoclassical growth model in Whelan (2003) and is isomorphic to the one in Greenwood, Hercowitz, and Krusell (1997), who choose a different normalization of the two technology shocks in their model. 
Figure 1

\section{Capital-to-Output Ratio in the United States (equipment and structures)}

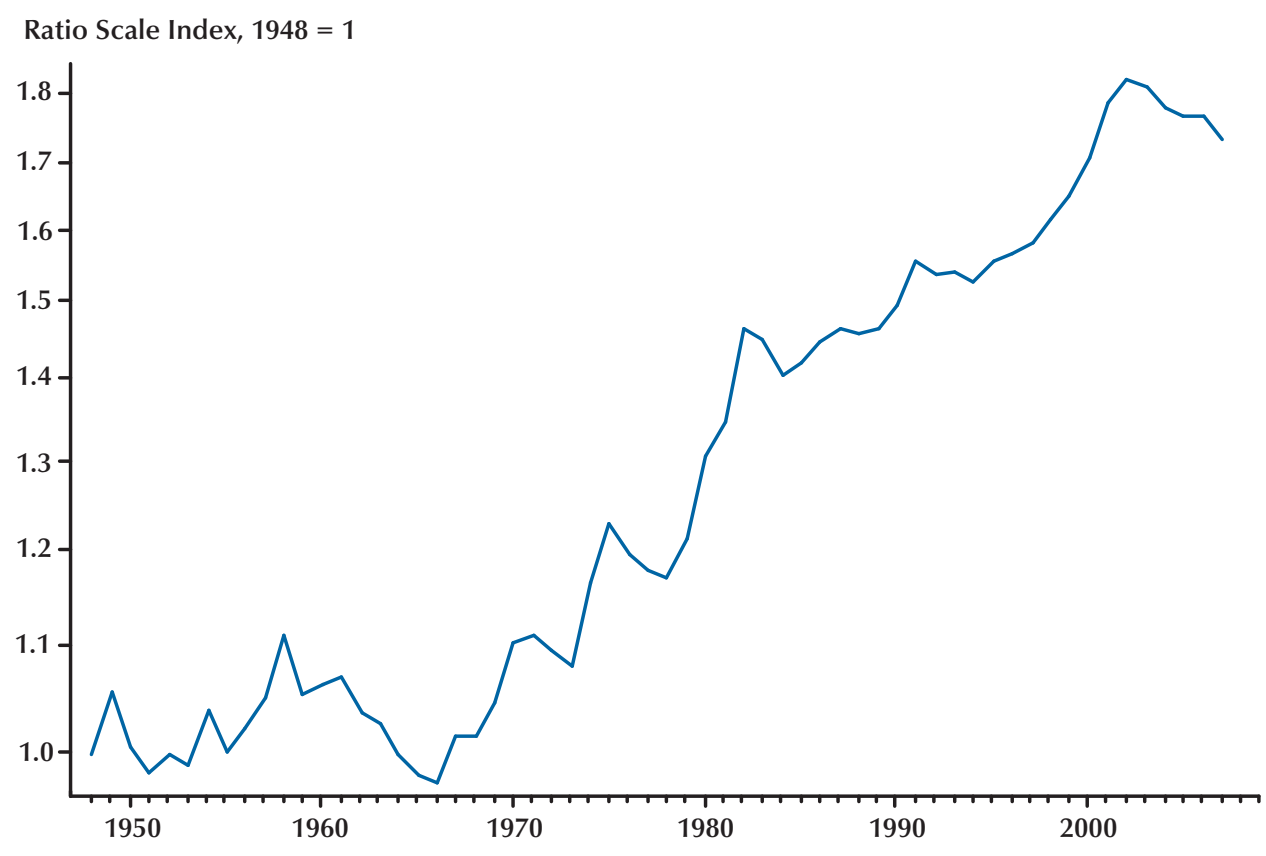

SOURCE: BLS multisector productivity database. Equipment and structures (i.e., fixed reproducible tangible capital) is calculated as a Tornquist index of the two categories. Standard Industrial Classification data (from www.bls.gov/mfp/historicalsic.htm) are spliced to North American Industry Classification System data (from www.bls.gov/mfp/mprdload.htm) starting at 1988 (data downloaded October 13, 2008).

$$
\begin{gathered}
I=K_{I}^{\alpha}\left(A_{I} L_{I}\right)^{1-\alpha} \\
C=Q K_{C}^{\alpha}\left(A_{I} L_{C}\right)^{1-\alpha} .
\end{gathered}
$$

In the consumption equation, we have implicitly defined labor-augmenting technological change as $A_{C}=Q^{1 /(1-\alpha)} A_{I}$ to decompose consumption technology into the product of investment technology, $A_{I}$, and a "consumption-specific" piece, $Q^{1 /(1-\alpha)}$. Let investment technology, $A_{I}$, grow at rate $g_{I}$ and the consumption-specific piece, $Q$, grow at rate $q$. Perfect competition and cost minimization imply that price equals marginal cost. If the sectors face the same factor prices (and the same rate of indirect business taxes), then

$$
\frac{P_{I}}{P_{C}}=\frac{M C^{C}}{M C^{I}}=Q \text {. }
$$

The sectors also choose to produce with the same capital-to-labor ratios, implying that $K_{I} / A_{I} L_{I}=$ $K_{C} / A_{I} L_{C}=K / A_{I} L$. We can then write the production functions as

$$
\begin{aligned}
& I=A_{I} L_{I}\left(K / A_{I} L\right)^{\alpha} \\
& C=Q A_{I} L_{C}\left(K / A_{I} L\right)^{\alpha} .
\end{aligned}
$$

We can now write the economy's budget constraint in a simple manner:

$$
Y^{\text {Inv. Units }} \equiv[I+C / Q]=A_{I}\left(L_{I}+L_{C}\right)\left(K / A_{I} L\right)^{\alpha},
$$

(4) or $y^{\text {Inv. Units }}=k^{\alpha}$, where

$$
y^{\text {Inv. Units }}=Y^{\text {Inv. Units }} / A_{I} L \text { and } k=K / A_{I} L .
$$

"Output" here is expressed in investment units, and "effective labor" is in terms of technology in the investment sector. The economy mechanically invests a share $s$ of nominal invest- 


\section{Figure 2}

\section{Price of Business Fixed Investment Relative to Other Goods and Services}

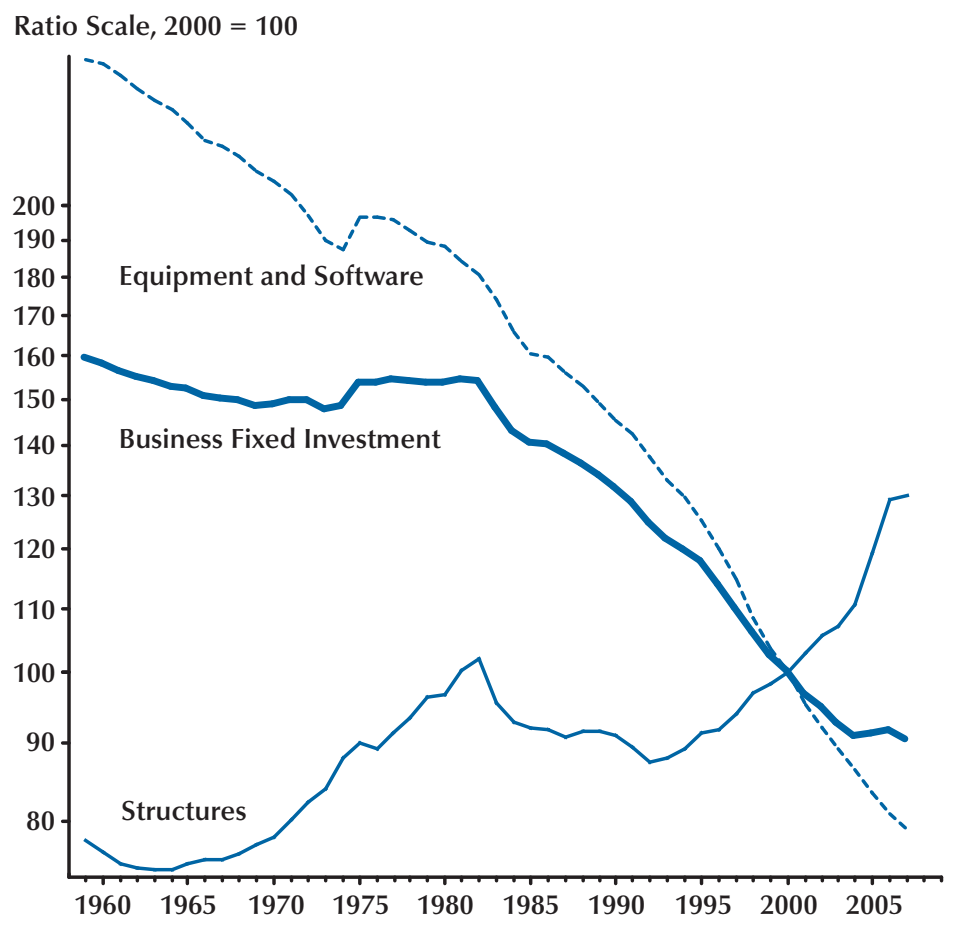

NOTE: "Other goods and services" constitutes business GDP less business fixed investment.

SOURCE: Bureau of Economic Analysis and authors' calculations.

ment, which implies that investment per effective unit of labor is $i=s \cdot y^{\text {Inv. Units }}{ }^{11}$ Capital accumulation then takes the same form as in the one-sector model, except that it is only growth in investment technology, $g_{I}$, that matters. In particular, in steady state,

$$
s y^{\text {Inv. Units }}=\left(n+\delta+g_{I}\right) k .
$$

The production function (4) and capitalaccumulation equation (5) correspond exactly to their one-sector counterparts. Hence, the dynamics of capital in this model reflect technology in the investment sector alone. In steady state, capital per unit of labor, $K / L$, grows at rate $g_{I}$, so the contribution of capital deepening to labor-productivity growth from equation (1) is

$11 s \cdot y^{\text {Inv. Units }}=\left[P_{I} I /\left(P_{I} I+P_{C} C\right)\right]\left[\left(I+P_{C} C / P_{I}\right) / A_{I} L\right]=I / A_{I} L$.

$$
\alpha g_{I}=\alpha \cdot \widehat{t f p_{I}} /(1-\alpha)
$$

Consumption technology in this model is "neutral" in that it does not affect investment or capital accumulation; the same result carries over to the Ramsey version of this model, with or without variable labor supply. (Basu et al., 2008, discuss the idea of consumption-technology neutrality in greater detail. ${ }^{12}$ )

To apply this model to the data, we need to decompose aggregate TFP growth (calculated from

${ }^{12}$ Note also that output in investment units is not equal to chain output in the national accounts. Chain gross domestic product (GDP) is

$$
\hat{Y}=s \hat{I}+(1-s) \hat{C}
$$

In contrast, in this model $\widehat{Y^{\text {Inv. Units }}}=s \hat{I}+(1-s) \hat{C}-(1-s) q$.

Hence, $\hat{Y}=\widehat{Y^{\text {Inv. Units }}}+(1-s) q$. 
chained output) into its consumption and investment components. Given the conditions so far, the following two equations hold:

$$
\begin{aligned}
& \widehat{t f p}=s \cdot \widehat{t f p}_{I}+(1-s) \widehat{t f p}_{C}, \\
& \widehat{P_{C}}-\widehat{P}_{I}=\widehat{t f p}_{C}-\widehat{t f p}_{I} .
\end{aligned}
$$

These are two equations in two unknowns-

$$
\widehat{t f p}_{I} \text { and } \widehat{t f p}_{C} \text {. }
$$

Hence, they allow us to decompose aggregate TFP growth into investment and consumption TFP growth. ${ }^{13}$

Table 2 shows that the two-sector growth model does, in fact, fit the data better. All derivations are done assuming an investment share of 0.15 , about equal to the nominal value of business fixed investment relative to the value of business output.

For the 1948-73 and 1973-95 periods, a comparison of columns 5 and 6 indicates that the model fits quite well-and much better than the one-sector model. The improved fit reflects that although overall TFP growth slowed very sharply, investment TFP growth (column 3) slowed much less. Hence, the slowdown in capital deepening was much smaller.

The steady-state predictions work less well for the periods after 1995, when actual capital deepening fell short of the steady-state prediction for capital deepening. During these periods, not only did overall TFP accelerate, but the relative price decline in column 2 also accelerated. Hence, implied investment TFP accelerated markedly (as did other TFP). Of course, the transition dynamics imply that capital deepening converges only slowly to the new steady state, and a decade is a relatively short time. (In addition, the pace of investment-sector TFP was particularly rapid in the late 1990s and has slowed somewhat in the 2000s.) So the more important point is that, quali-

\footnotetext{
${ }^{13}$ The calculations below use the official price deflators from the national accounts. Gordon (1990) argues that many equipment deflators are not sufficiently adjusted for quality improvements over time. Much of the macroeconomic literature since then has used the Gordon deflators (possibly extrapolated, as in Cummins and Violante, 2002). Of course, as Whelan (2003) points out, much of the discussion of biases in the consumer price index involves service prices, which also miss many quality improvements.
}

tatively, the model works in the right direction even over this relatively short period.

Despite these uncertainties, a bottom-line comparison of the one- and two-sector models is of interest. Suppose that the 1995-2007 rates of TFP growth continue to hold in both sectors (a big "if" discussed in the next section). Suppose also that the two-sector model fits well going forward, as it did in the 1948-95 period. Then we would project that future output per hour (like output per quality-adjusted unit of labor, shown in Tables 1 and 2) will grow on average about 0.75 percentage points per year faster than the onesector model would predict (1.38 versus 0.63 ), as a result of greater capital deepening. The difference is clearly substantial: It is a significant fraction of the average 2.15 percent growth rate in output per unit of labor (and 2.5 percent growth rate of output per hour) over the 1948-2007 period.

\section{PROJECTING THE FUTURE}

Forecasters, policymakers, and a number of academics regularly make "structured guesses" about the likely path of future growth. ${ }^{14}$ Not surprisingly, the usual approach is to assume that the future will look something like the past-but the challenge is to decide which parts of the past to include and which to downplay.

In making such predictions, economists often project average TFP growth for the economy as a whole. However, viewed through the lens of the two-sector model, one needs to make separate projections for TFP growth in both the investment and non-investment sectors. We consider three growth scenarios: low, medium, and high (Table 3).

Consider the medium scenario, which has output per hour growing at 2.3 (last column). Investment TFP is a bit slower than its average in the post-2000 period, reflecting that investment TFP has generally slowed since the burst of the late 1990s. Other TFP slows to its rate in

\footnotetext{
${ }^{14}$ Oliner and Sichel (2002) use the phrase "structured guesses." In addition to Oliner and Sichel, recent high-profile examples of projections have come from Jorgenson, Ho, and Stiroh (2008) and Gordon (2006). The CBO and the Council of Economic Advisers regularly include longer-run projections of potential output.
} 
Basu and Fernald

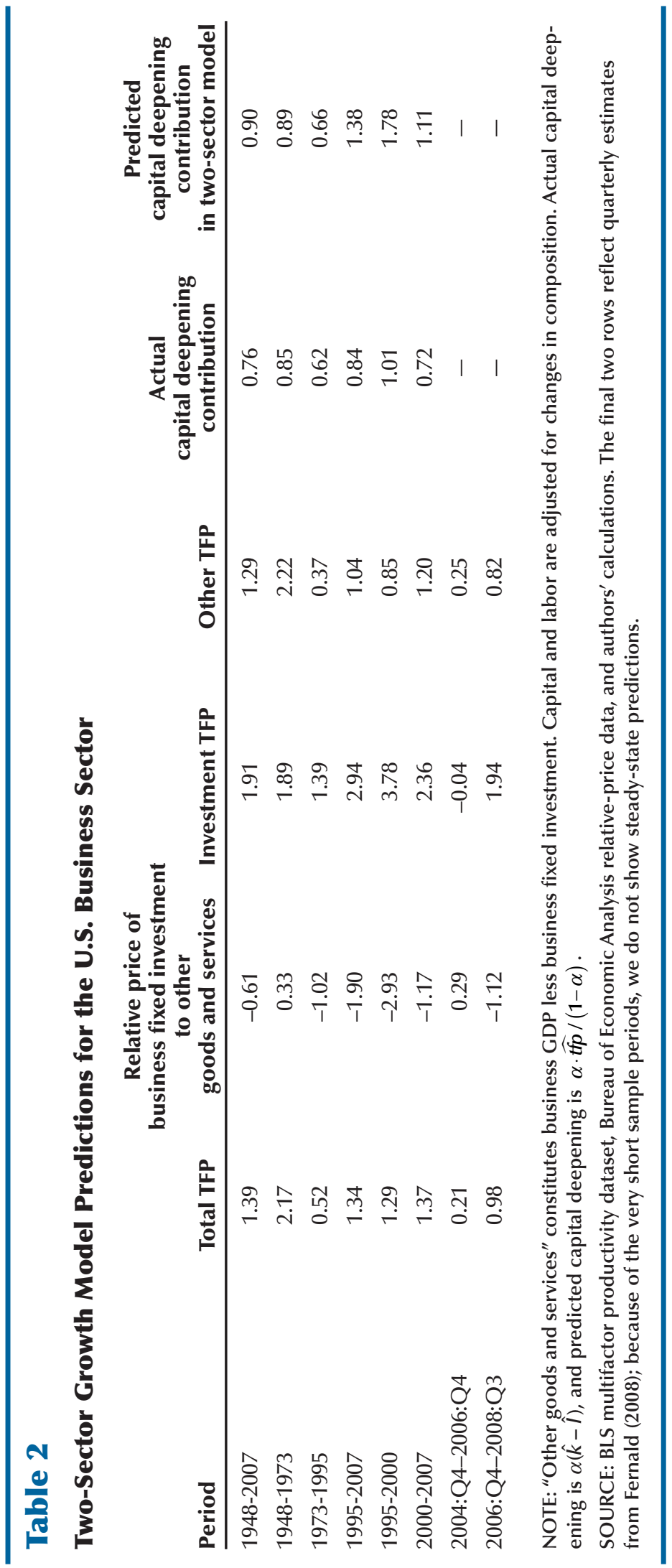


Table 3

A Range of Estimates for Steady-State Labor Productivity Growth

\begin{tabular}{|c|c|c|c|c|c|c|}
\hline Growth scenario & Investment TFP & Other TFP & Overall TFP & $\begin{array}{c}\text { Capital } \\
\text { deepening } \\
\text { contribution }\end{array}$ & $\begin{array}{c}\text { Labor } \\
\text { productivity }\end{array}$ & $\begin{array}{l}\text { Output per } \\
\text { hour worked }\end{array}$ \\
\hline Low & 1.00 & 0.70 & 0.7 & 0.5 & 1.2 & 1.5 \\
\hline Medium & 2.00 & 0.82 & 1.0 & 0.9 & 2.0 & 2.3 \\
\hline High & 2.50 & 1.10 & 1.3 & 1.2 & 2.5 & 2.8 \\
\hline
\end{tabular}

NOTE: Calculations assume an investment share of output of 0.15 and a capital share in production, $\alpha$, of 0.32 . Column 3 (Overall TFP) is an output-share-weighted average of columns 1 and 2 . Column 4 is column 1 multiplied by $\alpha /(1-\alpha)$. Column 5 is output per unit of composition-adjusted labor input and is the sum of columns 3 and 4 . Column 6 adds an assumed growth rate of labor quality/ composition of 0.3 percent per year, and therefore equals column 5 plus 0.3 percent.

the second half of the 1990s, reflecting an assumption that the experience of the early 2000s is unlikely to persist.

Productivity growth averaging about 2.25 percent is close to a consensus forecast. For example, in the first quarter of 2008, the median estimate in the Survey of Professional Forecasters (SPF, 2008) was for 2 percent labor-productivity growth over the next 10 years (and 2.75 percent gross domestic product [GDP] growth). In September 2008, the Congressional Budget Office estimated that labor productivity (in the nonfarm business sector) would grow at an average rate of about 2.2 percent between 2008 and 2018. ${ }^{15}$

As Table 3 clearly shows, however, small and plausible changes in assumptions-well within the range of recent experience-can make a large difference for steady-state growth projections. As a result, a wide range of plausible outcomes exists. In the SPF, the standard deviation across the 39 respondents for productivity growth over the next 10 years was about 0.4 percent-with a range of 0.9 to 3.0 percent. Indeed, the current median estimate of 2.0 percent is down from an estimate of 2.5 percent in 2005, but remains much higher than the one-year estimate of only 1.3 percent in $1997 .{ }^{16}$

\footnotetext{
${ }^{15}$ Calculated from data in CBO (2008).

${ }^{16}$ The SPF has been asking about long-run projections in the first quarter of each year since 1992. The data are available at www.philadelphiafed.org/research-and-data/real-time-center/ survey-of-professional-forecasters/data-files/PROD10/.
}

The two-sector model suggests several key questions in making long-run projections. First, what will be the pace of technical progress in producing information technology (IT) and, more broadly, equipment goods? For example, for hardware, Moore's law-that semiconductor capacity doubles approximately every two years-provides plausible bounds. For software, however, we really have very little firm ground for speculation.

Second, how elastic is the demand for IT? The previous discussion of the two-sector model assumed that the investment share was constant at 0.15 . But an important part of the price decline reflected that IT, for which prices have been falling rapidly, is becoming an increasing share of total business fixed investment. At some point, a constant share is a reasonable assumption and consistent with a balanced growth path. Yet over the next few decades, very different paths are possible. Technology optimists (such as DeLong, 2002) think that the elasticity of demand for IT exceeds unity, so that demand will rise even faster than prices fall. They think that firms and individuals will find many new uses for computers, semiconductors, and, indeed, information, as these commodities get cheaper and cheaper. By contrast, technology pessimists (such as Gordon, 2000) think that the greatest contribution of the IT revolution is in the past rather than the future. For example, firms may decide they will not need much more computing power in the future, so that as prices continue to fall, the nominal share 
of expenditure on IT will also fall. For example, new and faster computers might offer few advantages for word processing relative to existing computers, so the replacement cycle might become longer.

Third, what will happen to TFP in the non-ITproducing sectors? The range of uncertainty here is very large-larger, arguably, than for the first two questions. The general-purpose-technology nature of computing suggests that faster computers and better ability to manage and manipulate information might well lead to TFP improvements in computer-using sectors. ${ }^{17}$ For example, many important management innovations, such as the Wal-Mart business model or the widespread diffusion of warehouse automation, are made possible by cheap computing power. Productivity in research and development may also rise more directly; auto parts manufacturers, for example, can design new products on a computer rather than building physical prototype models. That is, computers may lower the cost and raise the returns to research and development

In addition, are these sorts of TFP spillovers from IT to non-IT sectors best considered as growth effects or level effects? For example, the "Wal-Martization" of retailing raises productivity levels (as more-efficient producers expand and less-efficient producers contract) but it does not necessarily boost long-run growth.

Fourth, the effects noted previously might well depend on labor market skills. Many endogenous growth models incorporate a key role for human capital, which is surely a key input into the innovation process-whether reflected in formal research and development or in management reorganizations. Beaudry, Doms, and Lewis (2006) find evidence that the intensity of personal computers use across U.S. cities is closely related to education levels in those cities.

We hope we have convinced readers that it is important to take a two-sector approach to esti-

\footnotetext{
${ }^{17}$ See, for example, Basu et al. (2003) for an interpretation of the broad-based TFP acceleration in terms of intangible organizational capital associated with using computers. Of course, an intangiblecapital story suggests that the measured share of capital is too low, and that measured capital is only a subset of all capital—so the model and calibration in the earlier section are incomplete.
}

mating the time path of long-run output. But as this (non-exhaustive) discussion demonstrates, knowing the correct framework for analysis is only one of many inputs to projecting potential output correctly. Much still remains unknown about potential output, even along a steady-state growth path. The biggest problem is the lack of knowledge about the deep sources of TFP growth.

\section{SHORT-RUN CONSIDERATIONS}

\section{General Issues in Defining and Estimating Short-Run Potential Output}

Traditionally, macroeconomists have taken the view expressed in Solow (1997) that, in the long-run, a growth model such as the ones described previously explains the economy's long-run behavior. Factor supplies and technology determine output, with little role for "demand" shocks. However, the short run was viewed very differently, when as Solow (1997) put it, “...fluctuations are predominantly driven by aggregate demand impulses" (p. 230).

Solow (1997) recognizes that real business cycle theories take a different view, providing a more unified vision of long-run growth and shortrun fluctuations than traditional Keynesian views did. Early real business cycle models, in particular, emphasized the role of high-frequency technology shocks. These models are also capable of generating fluctuations in response to nontechnological "demand" shocks, such as government spending. Since early real business cycle models typically do not incorporate distortions, they provide examples in which fluctuations driven by government spending or other impulses could well be optimal (taking the shocks themselves as given). Nevertheless, traditional Keynesian analyses often presumed that potential output was a smooth trend, so that any fluctuations were necessarily suboptimal (regardless of whether policy could do anything about them).

Fully specified New Keynesian models provide a way to think formally about the sources of business cycle fluctuations. These models are generally founded on a real business cycle model, albeit one with real distortions, such as firms 
having monopoly power. Because of sticky wages and/or prices, purely nominal shocks, such as monetary policy shocks, can affect real outcomes. The nominal rigidities also affect how the economy responds to real shocks, whether to technology, preferences, or government spending.

Short-run potential output is naturally defined as the rate of output the economy would have if there were no nominal rigidities, that is, by the responses in the real business cycle model underlying the sticky price model. ${ }^{18}$ This is our approach to producing a time series of potential output fluctuations in the short run.

In New Keynesian models, where prices and/or wages might adjust slowly toward their long-run equilibrium values, actual output might well deviate from this short-term measure of potential output. In many of these models, the "output gap"- - the difference between actual and potential output-is the key variable in determining the evolution of inflation. Kuttner (1994) and Laubach and Williams (2003) use this intuition to estimate the output gap as an unobserved component in a Phillips curve relationship. They find fairly substantial time variation in potential output.

In the context of New Keynesian DSGE models, is there any reason to think that potential output is a smooth series? At a minimum, a low variance of aggregate technology shocks as well as inelastic labor supply is needed. Rotemberg (2002), for example, suggests that because of slow diffusion of technology across producers, stochastic technological improvements might drive long-run growth without being an important factor at business cycle frequencies. ${ }^{19}$

\footnotetext{
${ }^{18}$ See Woodford (2003). There is a subtle issue in defining flexible price potential output when the time path of actual output may be influenced by nominal rigidities. In theory, the flexible price output series should be a purely forward-looking construct, which is generated by "turning off" all nominal rigidities in the model, but starting from current values of all state variables, including the capital stock. Of course, the current value of the capital stock might be different from what it would have been in a flexible price model with the same history of shocks because nominal rigidities operated in the past. Thus, in principle, the potential-output series should be generated by initializing a flexible price model every period, rather than taking an alternative time-series history from the flexible price model hit by the same sequence of real shocks. We do the latter rather than the former because we believe that nominal rigidities cause only small deviations in the capital stock, but it is possible that the resulting error in our potential-output series might actually be important.
}

Nevertheless, although a priori one might believe that technology changes only smoothly over time, there is scant evidence to support this position. Basu, Fernald, and Kimball (2006) control econometrically for nontechnological factors affecting the Solow residual-nonconstant returns to scale, variations in labor effort and capital's workweek, and various reallocation effects-and still find a "purified technology" residual that is highly variable. Alexopoulos (2006) uses publications of technical books as a proxy for unobserved technical change and finds that this series is not only highly volatile, but explains a substantial fraction of GDP and TFP. Finally, variance decompositions often suggest that innovations to technology explain a substantial share of the variance of output and inputs at business cycle frequencies; see Basu, Fernald, and Kimball (2006) and Fisher (2006).

When producing a time series of short-run potential output, it is necessary not only to know "the" correct model of the economy, but also the series of historical shocks that have affected the economy. One approach is to specify a model, which is often complex, and then use Bayesian methods to estimate the model parameters on the data. As a by-product, the model estimates the time series of all the shocks that the model allows. ${ }^{20}$ Because DSGE models are "structural" in the sense of Lucas's (1976) critique, one can perform counterfactual simulations-for example, by turning off nominal rigidities and using the estimated model and shocks to create a time series of flexible price potential output.

We do not use this approach because we are not sure that Bayesian estimation of DSGE models always uses reliable schemes to identify the relevant shocks. The full-information approach of these models is, of course, preferable in an efficiency sense-if one is sure that one has specified

\footnotetext{
${ }^{19}$ A recent paper by Justiniano and Primiceri (2008) estimates both simple and complex New Keynesian models and finds that most of the volatility in the flexible-wage/price economy reflects extreme volatility in markup shocks. They still estimate that there is considerable quarter-to-quarter volatility in technology, so that even if the only shocks were technology shocks, their flexible price measure of output would also have considerable volatility from one quarter to the next.

${ }^{20}$ See Smets and Wouters (2007).
} 
the correct structural model of the economy with all its frictions. We prefer to use limitedinformation methods to estimate the key shockstechnology shocks, in our case-and then feed them into small, plausibly calibrated models of fluctuations. At worst, our method should provide a robust, albeit inefficient, method of assessing some of the key findings of DSGE models estimated using Bayesian methods.

We believe that our method of estimating the key shocks is both more transparent in its identification and robust in its method because it does not rely on specifying correctly the full model of the economy, but only small pieces of such a model. As in the case of the Basu, Fernald, and Kimball (2006) procedure underlying our shock series, we specify only production functions and costs of varying factor utilization and assume that firms minimize costs-all standard elements of current "medium-scale" DSGE models. Furthermore, we assume that true technology shocks are orthogonal to other structural shocks, such as monetary policy shocks, which can therefore be used as instruments for estimation. Finally, because we do not have the overhead of specifying and estimating a complete structural general equilibrium model, we are able to model the production side of the economy in greater detail. Rather than assuming that an aggregate production function exists, we estimate industry-level production functions and aggregate technology shocks from these more disaggregated estimates. Basu and Fernald (1997) argue that this approach is preferable in principle and solves a number of puzzles in recent production-function estimation in practice.

We use time series of "purified" technology shocks, similar to those presented in Basu, Fernald, and Kimball (2006) and Basu et al. (2008). However, these series are at an annual frequency. Fernald (2008) applies the methods in these articles to quarterly data and produces higherfrequency estimates of technology shocks. Fernald estimates utilization-adjusted measures of TFP for the aggregate economy, as well as for the investment and consumption sector. In brief, aggregate TFP is measured using data from the BLS quarterly labor productivity data, combined with capital- service data estimated from detailed quarterly investment data. Labor quality and factor shares are interpolated from the BLS multifactorproductivity dataset. The relative price of investment goods is used to decompose aggregate TFP into investment and consumption components, using the (often-used) assumption that relative prices reflect relative TFPs. The utilization adjustment follows Basu, Fernald, and Kimball (2006), who use hours per worker as a proxy for utilization change (with an econometrically estimated coefficient) at an industry level. The input-output matrix was used to aggregate industry utilization change into investment and consumption utilization change, following Basu et al. (2008). ${ }^{21}$

To produce our estimated potential output series, we feed the technology shocks estimated by Fernald (2008) into simple one- and two-sector models of fluctuations (see the appendix). Technology shocks shift the production function directly, even if they are not amplified by changes in labor supply in response to variations in wages and interest rates. If labor supply is elastic, then a fortiori the changes in potential output will be more variable for any given series of technology shocks.

Elastic labor supply also allows nontechnology shocks to move short-run, flexible price output discontinuously. Shocks to government spending, even if financed by lump-sum taxes, cause changes in labor supply via a wealth effect. Shocks to distortionary tax rates on labor income shift labor demand and generally cause labor input, and hence output, to change. Shocks to the preference for consumption relative to leisure can also cause changes in output and its components.

The importance of all of these shocks for movements in flexible price potential output depends crucially on the size of the Frisch (wealth-constant) elasticity of labor supply. Unfortunately, this is one of the parameters in economics whose value is most controversial, at least at an aggregate level. Most macroeconomists assume values between 1 and 4 for this crucial

${ }^{21}$ Because of a lack of data at a quarterly frequency, Fernald (2008) does not correct for deviations from constant returns or for heterogeneity across industries in returns to scale-issues that Basu, Fernald, and Kimball (2006) argue are important. 
parameter, but not for particularly strong reasons. ${ }^{22}$ On the other hand, Card (1994) reviews both microeconomic and aggregative evidence and concludes there is little evidence in favor of a nonzero Frisch elasticity of labor supply. The canonical models of Hansen (1985) and Rogerson (1988) attempt to bridge the macro-micro divide. However, Mulligan (2001) argues that the strong implication of these models, an infinite aggregate labor supply elasticity, depends crucially on the assumption that workers are homogeneous and can easily disappear when one allows for heterogeneity in worker preferences.

We do not model real, nontechnological shocks to the economy in creating our series on potential output. Our decision is partly due to uncertainty over the correct value of the aggregate Frisch labor supply elasticity, which as discussed previously is crucial for calibrating the importance of such shocks. We also make this decision because in our judgment there is even less consensus in the literature over identifying true innovations to fiscal policy or to preferences than there is on identifying technology shocks. Our decision to ignore nontechnological real shocks clearly has the potential to bias our series on potential output, and depending on the values of key parameters, this bias could be significant.

\section{One-Sector versus Two-Sector Models}

In the canonical New Keynesian Phillips curve, derived with Calvo price setting and flexible wages, inflation today depends on expected inflation tomorrow, as well as on the gap between actual output and the level of output that would occur with flexible prices.

To assess how potential and actual output respond in the short run in a one- versus twosector model, we used a very simple two-sector New Keynesian model (see the appendix). As in the long-run model, we assume that investment

\footnotetext{
${ }^{22}$ In many cases, it is simply because macro models do not "work"that is, display sufficient amplification of shocks-for smaller values of the Frisch labor supply elasticity. In other cases, values like 4 are rationalized by assuming, without independent evidence, that the representative consumer's utility from leisure takes the logarithmic form. However, this restriction is not imposed by the King-Plosser-Rebelo (1988) utility function, which guarantees balanced growth for any value of the Frisch elasticity.
}

and consumption production uses a Cobb-Douglas technology with the same factor shares but with a (potentially) different multiplicative technology parameter. To keep things simple, factors are completely mobile, so that a one-sector model is the special case when the same technology shock hits both sectors.

We simulated the one- and two-sector models using the utilization-adjusted technology shocks estimated in Fernald (2008). Table 4 shows standard deviations of selected variables in flexible and sticky price versions of the one- and twosector models, along with actual data for the U.S. economy.

The model does a reasonable job of approximating the variation in actual data, considering how simple it is and that only technology shocks are included. Investment in the data is slightly less volatile than either in the sticky price model or the two-sector flexible price model. This is not surprising, given that the model does not have any adjustment costs or other mechanisms to smooth out investment. Consumption, labor, and output in the data are more volatile than in the models. ${ }^{23}$ Additional shocks (e.g., to government spending, monetary policy, or preferences) would presumably add volatility to model simulations.

An important observation from Table 4 is that potential output-the flexible price simulations, in either the one- or two-sector variants-is highly variable, roughly as variable as sticky price output. The short-run variability of potential output in New Keynesian models has been emphasized by Neiss and Nelson (2005) and Edge, Kiley, and Laforte (2007).

These models, with the shocks we have added, show a very high correlation of flexible and sticky price output. In the two-sector case, the correlation is 0.91 . Nevertheless, the implied output gap (shown in the penultimate line of Table 4 as the difference between output in the flexible and sticky price cases) is more volatile than would be implied if potential output were estimated with the one-sector model (the final line).

\footnotetext{
${ }^{23}$ The relative volatility of consumption is not that surprising, because the models do not have consumer durables and we have not yet analyzed consumption of nondurables and services in the actual data.
} 


\section{Table 4}

\section{Standard Deviations, Model Simulations, and Data}

\begin{tabular}{lcccc} 
Variable & Investment & Consumption & Labor & Output \\
\hline One-sector, flexible price & 4.40 & 0.81 & 0.47 & 1.52 \\
Two-sector, flexible price & 6.28 & 0.89 & 0.73 & 1.66 \\
One-sector, sticky price & 4.82 & 0.84 & 0.64 & 1.60 \\
Two-sector, sticky price & 5.52 & 0.87 & 0.85 & 1.14 \\
Data & 4.54 & 1.12 & 0.96 & 0.72 \\
Output gap (two-sector sticky price & 5.78 & 0.59 & & 0.59 \\
less two-sector flexible price) & & & 0.18 \\
"One-sector" estimated gap (two-sector sticky price & 2.55 & & & 0.41 \\
less one-sector flexible price) & & &
\end{tabular}

NOTE: Model simulations use utilization-adjusted TFP shocks from Fernald (2008). Two-sector simulations use estimated quarterly consumption and investment technology; one-sector simulations use the same aggregate shock (a share-weighted average of the two sectoral shocks) in both sectors. All variables are filtered with the Christiano-Fitzgerald bandpass filter to extract variation between 6 and 32 quarters.

Figure 3 shows that the assumption that potential output has no business cycle variationwhich is tantamount to using (Hodrick-Prescottfiltered) sticky price output itself as a proxy for the output gap-would overestimate the variation in the output gap. This would not matter too much if the output gap were perfectly correlated with sticky price output itself-then, at least, the sign, if not the magnitude, would be correct. However, as the figure shows, the "true" two-sector output gap in the model (two-sector sticky price output less two-sector flexible price output) is imperfectly correlated with sticky price output-indeed, the correlation is only 0.25 . So in this model, policymakers could easily be misled by focusing solely on output fluctuations rather than the output gap.

\section{Implications for Stabilization Policy}

If potential output fluctuates substantially over time, then this has potential implications for the desirability of stabilization policy. In particular, policymakers should be focused only on stabilizing undesirable fluctuations.

Of course, the welfare benefits of such policies remain controversial. Lucas $(1987,2003)$ famously argued that, given the fluctuations we observe, the welfare gains from additional stabilization of the economy are likely to be small. In particular, given standard preferences and the observed variance of consumption (around a linear trend), a representative consumer would be willing to reduce his or her average consumption by only about $1 / 2$ of $1 / 10$ th of 1 percent in exchange for eliminating all remaining variability in consumption. Note that this calculation does not necessarily imply that stabilization policy does not matter, because the calculation takes as given the stabilization policies implemented in the past. Stabilization policies might well have been valuable-for example, in eliminating recurrences of the Great Depression or by minimizing the frequency of severe recessions-but additional stabilization might not offer large benefits.

This calculation amounts to some $\$ 5$ billion per year in the United States, or about \$16 per person. Compared with the premiums we pay for very partial insurance (e.g., for collision coverage on our cars), this is almost implausibly low. Any politician would surely vote to pay $\$ 5$ billion for a policy that would eliminate recessions.

Hence, a sizable literature considers ways to obtain larger costs of business cycle fluctuations, with mixed results. Arguments in favor of stabilization include Galí, Gertler, and López-Salido (2007), who argue that the welfare effects of booms 
Figure 3

\section{Output Gap and Sticky Price Output}

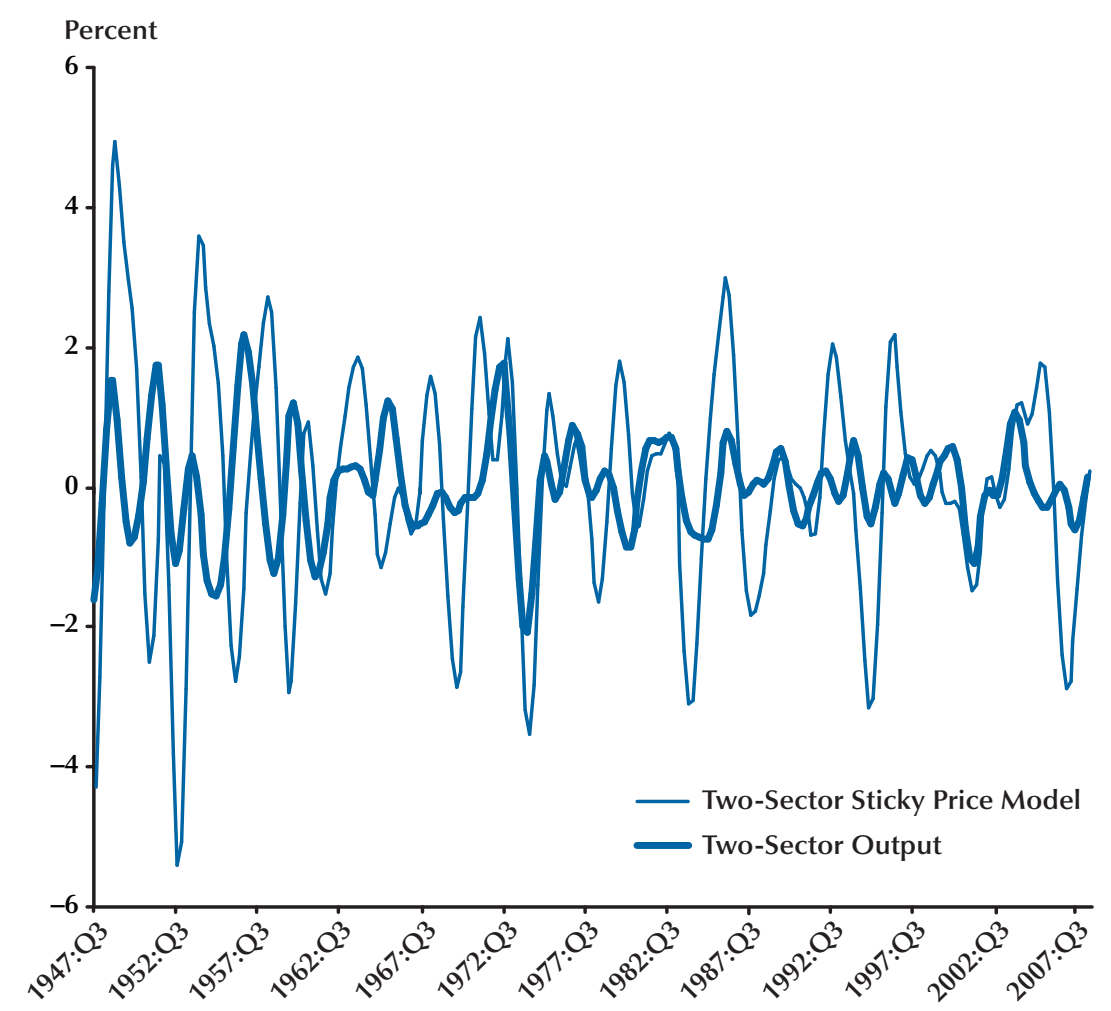

NOTE: Bandpass-filtered (6 to 32 quarters) output from two-sector sticky price model and the corresponding output gap (defined as sticky price output less flexible price output).

and recessions may be asymmetric. In particular, because of wage and price markups, steady-state employment and output are inefficiently low in their model, so that the costs of fluctuations depend on how far the economy is from full employment. Recessions are particularly costlywelfare falls by more during a business cycle downturn than it rises during a symmetric expansion. Barlevy (2004) argues in an endogenousgrowth framework that stabilization might increase the economy's long-run growth rate; this allowed him to obtain very large welfare effects from business cycle volatility.

This discussion of welfare effects highlights that much work remains to understand the desirability of observed fluctuations, the ability of policy to smooth the undesirable fluctuations in the output gap, and the welfare benefits of such policies.

\section{WHAT IS CURRENT POTENTIAL OUTPUT GROWTH?}

Consider the current situation, as of late 2008: Is potential output growth relatively high, relatively low, or close to its steady-state value? ${ }^{24}$ The answer is important for policymakers, where statements by the Federal Open Market Committee (FOMC) participants have emphasized the impor-

\footnotetext{
${ }^{24}$ We could, equivalently, discuss the magnitude or even sign of the output gap, which is naturally defined in levels. The level is the integral of the growth rates, of course, and growth rates make it a little easier to focus, at least implicitly, on how the output gap is likely to change over time.
} 
tance of economic weakness in reducing inflationary pressures. ${ }^{25}$ Moreover, a discussion of the issue highlights some of what we know, and do not know, about potential output. Some of the considerations are closely linked to earlier points we have made, but these considerations also allow a discussion of other issues that are not included in the simple models discussed here.

Several arguments suggest that potential output growth might currently be running at a relatively rapid pace. First, and perhaps most importantly, TFP growth has been relatively rapid from the end of 2006 through the third quarter of 2008 (see Table 2). During this period output growth itself was relatively weak, and hours per worker were generally falling; hence, following the logic in Basu, Fernald, and Kimball (2006), factor utilization appears to have been falling as well. As a result, in both the consumption and the investment sectors, utilization-adjusted TFP (from Fernald, 2008) has grown at a more rapid pace than its post-1995 average. This fast pace has occurred despite the reallocations of resources away from housing and finance and the high level of financial stress.

Second, substantial declines in wealth are likely to increase desired labor supply. Most obviously, housing wealth has fallen and stock market values have plunged; but tax and expenditure policies aimed at stabilizing the economy could also suggest a higher present value of taxes. Declining wealth has a direct, positive effect on labor supply. In addition, as the logic of Campbell and Hercowitz (2006) would imply, rising financial stress could lead to increases in labor supply as workers need to acquire larger down payments for purchases of consumer durables. And if there is habit persistence in consumption, workers might also seek, at least temporarily, to work more hours to smooth the effects of shocks to gasoline and food prices.

Nevertheless, there are also reasons to be concerned that potential output growth is currently lower than its pace over the past decade or so.

\footnotetext{
${ }^{25}$ For example, in the minutes from the September 2008 FOMC meeting, participants forecast that over time "increased economic slack would tend to damp inflation" (Board of Governors, 2008).
}

First, Phelps (2008) raises the possibility that because of a sectoral shift away from housingrelated activities and finance, potential output growth is temporarily low and the natural rate of unemployment is temporarily high. Although qualitatively suggestive, it is unclear that the sectoral shifts argument is quantitatively important. For example, Valletta and Cleary (2008) look at the (weighted) dispersion of employment growth across industries, a measure used by Lilien (1982). They find that as of the third quarter of 2008, "the degree of sectoral reallocation...remains low relative to past economic downturns." Valletta and Cleary (2008) also consider job vacancy data, which Abraham and Katz (1986) suggest could help distinguish between sectoral shifts and pure cyclical increases in unemployment and employment dispersion. The basic logic is that in a sectoral shifts story, expanding firms should have high vacancies that partially or completely offset the low vacancies in contracting firms. Valletta and Cleary find that the vacancy rate has been steadily falling since late 2006. ${ }^{26}$

Third, Bloom (2008) argues that uncertainty shocks are likely to lead to a sharp decline in output. As he puts it, there has been "a huge surge in uncertainty that is generating a rapid slow-down in activity, a collapse of banking preventing many of the few remaining firms and consumers that want to invest from doing so, and a shift in the political landscape locking in the damage through protectionism and anti-competitive policies" (p. 4). His argument is based on the model simulations in Bloom (2007), in which an increase in macro uncertainty causes firms to temporarily pause investment and hiring. In his model, productivity growth also falls temporarily because of reduced reallocation from lower- to higherproductivity establishments.

Fourth, the credit freeze could directly reduce productivity-improving reallocations, along the lines suggested by Bloom (2007), as well as Eisfeldt and Rampini (2006). Eisfeldt and Rampini argue that, empirically, capital reallocation is procycli-

\footnotetext{
${ }^{26}$ Valletta and Cleary do find some evidence that the U.S. Beveridge curve might have shifted out in recent quarters relative to its position from 2000 to 2006.
} 
cal, whereas the benefits (reflecting cross-sectional dispersion of marginal products) are countercyclical. These observations suggest that the informational and contractual frictions, including financing constraints, are higher in recessions. The situation as of late 2008 is one in which financing constraints are particularly severe, which is likely to reduce efficient reallocations of both capital and labor.

Fifth, there could be other effects from the seize-up of financial markets in 2008. Financial intermediation is an important intermediate input into production in all sectors. If it is complementary with other inputs (as in Jones, 2008), for example, you need access to the commercial paper market to finance working capital needsthen it could lead to substantial disruptions of real operations.

Finally, the substantial volatility in commodity prices, especially oil, in recent years could affect potential output. That said, although oil is a crucial intermediate input into production, changes in oil prices do not have a clear-cut effect on TFP, measured as domestic value added relative to primary inputs of capital and labor. They might, nevertheless, influence equilibrium output by affecting equilibrium labor supply. Blanchard and Galí (2007) and Bodenstein, Erceg, and Guerrieri (2008), however, are two recent analyses in which, because of (standard) separable preferences, there is no effect on flexible price GDP or employment from changes in oil prices. So there is no a priori reason to expect fluctuations in oil prices to have a substantial effect on the level or growth rate of potential output.

A difficulty for all these arguments that potential output growth might be temporarily low is the observation already made, that productivity growth (especially after adjusting for utilization) has, in fact, been relatively rapid over the past seven quarters.

It is possible the productivity data have been

\footnotetext{
${ }^{27}$ Note also that the data are all subject to revision. For example, the annual revision in 2009 will revise data from 2006 forward. In addition, labor-productivity data for the nonfinancial corporate sector, which is based on income-side rather than expenditure-side data, show less of a slowdown in 2005 and 2006 and less of a pickup since then. That said, even the nonfinancial corporate productivity numbers have remained relatively strong in the past few years.
}

mismeasured in recent quarters. ${ }^{27}$ Basu, Fernald, and Shapiro (2001) highlight variations in disruption costs associated with tangible investment. Comparing 2004:Q4-2006:Q4 (when productivity growth was weak) with 2006:Q4-2008:Q3 (when productivity was strong), growth in business fixed investment was very similar, suggesting that timevarying disruption costs probably explain little of the recent variation in productivity growth rates.

Basu et al. (2004) and Oliner, Sichel, and Stiroh (2007) discuss the role of mismeasurement associated with intangible investments, such as organizational changes associated with IT. With greater concerns about credit and cash flow, firms might have deferred organizational investments and reallocations; in the short run, such deferral would imply faster measured productivity growth, even if true productivity growth (in terms of total output, the sum of measured output plus unobserved intangible investment) were constant. Basu et al. (2004) argue for a link between observed investments in computer equipment and unobserved intangible investments in organizational change. Growth in computer and software investment does not show a notable difference between the 2004:Q4-2006:Q4 and 2006:Q4-2008:Q3 periods. If anything, the investment rate was higher in the latter period-so that this proxy again does not imply mismeasurement.

Given wealth effects on labor supply and strong recent productivity performance-along with the failure of typical proxies for mismeasurement to explain the productivity performancethere are reasons for optimism about the short-run pace of potential output growth. Nevertheless, the major effects of the adverse shocks on potential output seem likely to be ahead of us. For example, the widespread seize-up of financial markets has been especially pronounced only in the second half of 2008. We expect that as the effects of the collapse in financial intermediation, the surge in uncertainty, and the resulting declines in factor reallocation play out over the next several years, short-run potential output growth will be constrained relative to where it otherwise would have been. 


\section{CONCLUSION}

This article has highlighted a few things we think we know about potential output-namely, the importance in both the short run and the long run of rapid technological change in producing equipment investment goods and the likely time variation in the short-run growth rate of potential. Our discussion of these points has, of course, pointed toward some of the many things we do not know.

Taking a step back, we have advocated thinking about policy in the context of explicit models that suggest ways to think about the world economy, including potential output. But there is an important interplay between theory and measurement, as the discussion suggests. Every day, policymakers grapple with challenges that are not present in the standard models. Not only do they not know the true model of the economy, they also do not know the current state variables or the shocks with any precision; and the environment is potentially nonstationary, with the continuing question of whether structural change (e.g., parameter drift) has occurred. Theory (and practical experience) tells us that our measurements are imperfect, particularly in real time. Not surprisingly, central bankers look at many of the real-time indicators and filter them analytically-relying on theory and experience. Estimating potential output growth is one modest and relatively transparent example of this interplay between theory and measurement.

\section{REFERENCES}

Abraham, Katharine G. and Katz, Lawrence K. "Cyclical Unemployment: Sectoral Shifts or Aggregate Disturbances?" Journal of Political Economy, June 1986, 94(3), pp. 507-22.

Alexopoulos, Michelle. "Read All About It! What Happens Following a Technology Shock.” Working Paper, University of Toronto, April 2006.

Barlevy, Gadi. "The Cost of Business Cycles Under Endogenous Growth." American Economic Review, September 2004, 94(4), pp. 964-90.
Basu, Susanto and Fernald, John G. "Returns to Scale in U.S. Production: Estimates and Implications." Journal of Political Economy, April 1997, 105(2), pp. 249-83.

Basu, Susanto and Fernald, John G. "Aggregate Productivity and Aggregate Technology." European Economic Review, June 2002, 46(6), pp. 963-91.

Basu, Susanto; Fernald, John G. and Kimball, Miles S. "Are Technology Improvements Contractionary?" American Economic Review, December 2006, 96(5), 1418-48.

Basu, Susanto; Fernald, John G.; Oulton, Nicholas and Srinivasan, Sylaja. "The Case of the Missing Productivity Growth: Or, Does Information Technology Explain Why Productivity Accelerated in the United States but Not the United Kingdom?" in M. Gertler and K. Rogoff, eds., NBER Macroeconomics Annual 2003. Cambridge, MA: MIT Press, 2004, pp. 9-63.

Basu, Susanto; Fernald, John G. and Shapiro, Matthew D. "Productivity Growth in the 1990s: Technology, Utilization, or Adjustment?” CarnegieRochester Conference Series on Public Policy, December 2001, 55(1), pp. 117-65.

Basu, Susanto; Fisher, Jonas; Fernald, John G. and Miles, Kimball S. "Sector-Specific Technical Change." Unpublished manuscript, University of Michigan, 2008.

Basu, Susanto and Kimball, Miles. "Long Run Labor Supply and the Elasticity of Intertemporal Substitution for Consumption." Unpublished manuscript, University of Michigan, October 2002; www-personal.umich.edu/ mkimball/pdf/ cee_oct02-3.pdf.

Beaudry, Paul; Doms, Mark and Lewis, Ethan. "Endogenous Skill Bias in Technology Adoption: City-Level Evidence from the IT Revolution." Working Paper No. 2006-24, Federal Reserve Bank of San Francisco, August 2006; www.frbsf.org/ publications/economics/papers/2006/wp06-24bk.pdf.

Blanchard, Olivier, J. and Galí, Jordi. "The Macroeconomic Effects of Oil Price Shocks: Why 


\section{Basu and Fernald}

Are the 2000s So Different from the 1970s?" Working Paper No. 07-01, MIT Department of Economics, August 18, 2007.

Bloom, Nicholas. "The Impact of Uncertainty Shocks." NBER Working Paper No. 13385, National Bureau of Economic Research, September 2007; www.nber.org/papers/w13385.pdf.

Bloom, Nicholas. "The Credit Crunch May Cause Another Great Depression.” Stanford University Department of Economics, October 8, 2008; www.stanford.edu/ nbloom/CreditCrunchII.pdf.

Board of Governors of the Federal Reserve System. Minutes of the Federal Open Market Committee. September 16, 2008; www.federalreserve.gov/ monetarypolicy/fomcminutes20080916.htm.

Bodenstein, Martin; Erceg, Christopher E. and Guerrieri, Luca. "Optimal Monetary Policy with Distinct Core and Headline Inflation Rates." International Finance Discussion Papers 941, Board of Governors of the Federal Reserve System, August 2008; www.federalreserve.gov/pubs/ifdp/ 2008/941/ifdp941.pdf.

Calvo, Guillermo. "Staggered Prices in a UtilityMaximizing Framework," Journal of Monetary Economics, September 1983, 12(3), pp. 383-98.

Campbell, Jeffrey and Hercowitz, Zvi. "The Role of Collateralized Household Debt in Macroeconomic Stabilization." Working Paper No. 2004-24, Federal Reserve Bank of Chicago, revised December 2006; www.chicagofed.org/economic_research_and_data/ publication_display.cfm?Publication=6\&year $=$ $2000 \% 20$ AND $\% 202005$.

Card, David. "Intertemporal Labor Supply: An Assessment," in C.A. Sims, ed., Advances in Econometrics. Volume 2, Sixth World Congress. New York: Cambridge University Press, 1994, pp. 49-80.

Congressional Budget Office. "CBO's Method for Estimating Potential Output: An Update.” August 2001; www.cbo.gov/ftpdocs/30xx/doc3020/ PotentialOutput.pdf.
Congressional Budget Office. "A Summary of Alternative Methods for Estimating Potential GDP." March 2004; www.cbo.gov/ftpdocs/51xx/doc5191/ 03-16-GDP.pdf.

Congressional Budget Office. "Key Assumptions in CBO's Projection of Potential Output" (by calendar year) in The Budget and Economic Outlook: An Update. September 2008, Table 2-2; www.cbo.gov/ ftpdocs/97xx/doc9706/Background_Table2-2.xls.

Cummins, Jason G. and Violante, Giovanni L. "Investment-Specific Technical Change in the US (1947-2000): Measurement and Macroeconomic Consequences." Review of Economic Dynamics, April 2002, 5(2), pp. 243-84.

DeLong, J. Bradford. "Productivity Growth in the 2000s," in M. Gertler and K. Rogoff, eds., NBER Macroeconomics Annual 2002. Cambridge, MA: MIT Press, 2003.

Edge, Rochelle M.; Kiley, Michael T. and Laforte, Jean-Philippe. "Natural Rate Measures in an Estimated DSGE Model of the U.S. Economy." Finance and Economics Discussion Series 2007-08, Board of Governors of the Federal Reserve System, March 26, 2007; www.federalreserve.gov/pubs/ feds/2007/200708/200708pap.pdf.

Eisfeldt, Andrea and Rampini, Adriano. "Capital Reallocation and Liquidity." Journal of Monetary Economics, April 2006, 53(3), pp. 369-99.

Elsby, Michael and Shapiro, Matthew. "Stepping Off the Wage Escalator: A Theory of the Equilibrium Employment Rate.” Unpublished manuscript, April 2008; www.eief.it/it/files/2008/04/steppingoff-2008-04-01.pdf.

Fernald, John G. "A Quarterly Utilization-Adjusted Measure of Total Factor Productivity.” Unpublished manuscript, 2008.

Fisher, Jonas. "The Dynamic Effects of Neutral and Investment-Specific Technology Shocks." Journal of Political Economy, June 2006, 114(3), pp. 413-52.

Galí, Jordi; Gertler, Mark and Lopez-Salido, David J. "Markups, Gaps, and the Welfare Costs of Business 
Fluctuations." Review of Economics and Statistics, November 2007, 89, pp. 44-59.

Gordon, Robert J. The Measurement of Durable Goods Prices. Chicago: University of Chicago Press, 1990.

Gordon, Robert J. "Does the 'New Economy' Measure up to the Great Inventions of the Past?" Journal of Economic Perspectives, Fall 2000, 4(14), pp. 49-74.

Gordon, Robert J. "Future U.S. Productivity Growth: Looking Ahead by Looking Back." Presented at the Workshop at the Occasion of Angus Maddison's 80th Birthday, World Economic Performance: Past, Present, and Future, University of Groningen, Netherlands, October 27, 2006.

Greenwood, Jeremy; Hercowitz, Zvi and Krusell, Per. "Long-Run Implications of Investment-Specific Technological Change.” American Economic Review, June 1997, 87(3), pp. 342-62.

Hansen, Gary. "Indivisible Labor and the Business Cycle." Journal of Monetary Economics, November 1985, 16, pp. 309-37.

Jones, Chad. "R\&D-Based Models of Economic Growth.” Journal of Political Economy, August 1995, 103, pp. 759-84.

Jones, Chad. "Sources of U.S. Economic Growth in a World of Ideas." American Economic Review, March 2002, 92(1), pp. 220-39.

Jones, Chad. "Intermediate Goods and Weak Links: A Theory of Economic Development." NBER Working Paper No. 13834, National Bureau of Economic Research, September 2008; www.nber.org/papers/w13834.pdf.

Jorgenson, Dale W.; Gollop, Frank M. and Fraumeni, Barbara M. Productivity and U.S. Economic Growth. Cambridge, MA: Harvard University Press, 1987.

Jorgenson, Dale W. "Information Technology and the U.S. Economy.” American Economic Review, March 2001, 91(1), pp. 1-32.

Jorgenson, Dale W.; Ho, Mun S. and Stiroh, Kevin J. "A Retrospective Look at the U.S. Productivity
Growth Resurgence." Journal of Economic Perspectives, Winter 2008, 22(1), pp. 3-24.

Justiniano, Alehandro and Primiceri, Giorgio. "Potential and Natural Output." Unpublished manuscript, Northwestern University, June 2008; http://faculty.wcas.northwestern.edu/ gep575/ JPgap8_gt.pdf.

King, Robert G.; Plosser, Charles I. and Rebelo, Sergio T. "Production, Growth and Business Cycles: I. The Basic Neoclassical Model." Journal of Monetary Economics, 1988, 21(2-3), pp. 195-232.

Kuttner, Kenneth. "Estimating Potential Output as a Latent Variable." Journal of Business and Economic Statistics, July 1994, 12(3), pp. 361-68.

Kydland, Finn E. and Prescott, Edward C. "Rules Rather than Discretion: The Inconsistency of Optimal Plans." Journal of Political Economy, June 1977, 85(3), pp. 473-92.

Laubach, Thomas and Williams, John C. "Measuring the Natural Rate of Interest." Review of Economics and Statistics, November 2003, 85(4), pp. 1063-70.

Lilien, David M. "Sectoral Shifts and Cyclical Unemployment." Journal of Political Economy, August 1982, 90(4), pp. 777-93.

Lucas, Robert E. Jr. "Econometric Policy Evaluation: A Critique." Carnegie-Rochester Conference Series on Public Policy, 1976, 1(1), pp. 19-46.

Lucas, Robert E. Jr. Models of Business Cycles. Oxford: Basil Blackwell Ltd, 1987.

Lucas, Robert E. Jr. "Macroeconomic Priorities." American Economic Review, March 2003, 93(1), pp. 1-14.

Mulligan, Casey. "Aggregate Implications of Indivisible Labor." Advances in Macroeconomics, 2001, 1(1), Article 4; www.bepress.com/cgi/ viewcontent.cgi ?article=1007\&context=bejm .

Neiss, Katherine and Nelson, Edward. "Inflation Dynamics, Marginal Cost, and the Output Gap: Evidence from Three Countries." Journal of Money, 


\section{Basu and Fernald}

Credit, and Banking, December 2005, 37(6), pp. 1019-45.

Okun, Arthur, M. The Political Economy of Prosperity. Washington, DC: Brookings Institution, 1970.

Oliner, Stephen D. and Sichel, Daniel E. "The Resurgence of Growth in the Late 1990s: Is Information Technology the Story?" Journal of Economic Perspectives, Fall 2000, 14(4), pp. 3-22.

Oliner, Stephen D. and Sichel, Daniel E. "Information Technology and Productivity: Where Are We Now and Where Are We Going?" Federal Reserve Bank of Atlanta Economic Review, Third Quarter 2002, pp. 15-44; www.frbatlanta.org/filelegacydocs/ oliner_sichel_q302.pdf.

Oliner, Stephen D.; Sichel, Daniel and Stiroh, Kevin. "Explaining a Productive Decade." Brookings Papers on Economic Activity, 2007, 1, pp. 81-137.

Organisation of Economic Co-operation and Development. Revisions of Quarterly Output Gap Estimates for 15 OECD Member Countries. September 26, 2008; www.oecd.org/dataoecd/15/6/41149504.pdf.

Phelps, Edmund S. "U.S. Monetary Policy and the Prospective Structural Slump.” Presented at the 7th Annual BIS Monetary Policy Conference, Lucerne, June 26-27, 2008; www.bis.org/events/conf080626/phelps.pdf.

Rogerson, Richard. "Indivisible Labor, Lotteries and Equilibrium." Journal of Monetary Economics, January 1988, 21(1), pp. 3-16.
Rotemberg, Julio J. "Stochastic Technical Progress, Nearly Smooth Trends and Distinct Business Cycles.” NBER Working Paper 8919, National Bureau of Economic Research, May 2002; papers.ssrn.com/sol3/papers.cfm?abstract_id=310466.

Smets, Frank and Wouters, Rafael. "Shocks and Frictions in US Business Cycles: A Bayesian DSGE Approach." American Economic Review, June 2007, 97(3), pp. 586-606.

Survey of Professional Forecasters. Survey from First Quarter 2008. February 12, 2008;

www.philadelphiafed.org/ research-and-data/realtime-center/survey-of-professional-forecasters/2008/ spfq108.pdf.

Solow, Robert M. "Is There a Core of Usable Macroeconomics We Should All Believe In?" American Economic Review, May 1997, 87(2), pp. 230-32.

Valletta, Robert and Cleary, Aisling. "Sectoral Reallocation and Unemployment." Federal Reserve Bank of San Francisco FRBSF Economic Letter, No. 2008-32, October 17, 2008; www.frbsf.org/ publications/economics/letter/2008/el2008-32.pdf.

Whelan, Karl. "A Two-Sector Approach to Modeling U.S. NIPA Data." Journal of Money, Credit, and Banking, August 2003, 35(4), pp. 627-56.

Woodford, Michael. Interest and Prices: Foundations of a Theory of Monetary Policy. Princeton, NJ: Princeton University Press, 2003. 


\section{APPENDIX}

\section{A SIMPLE TWO-SECTOR STICKY PRICE MODEL ${ }^{28}$}

\section{Households}

The economy is populated by a representative household which maximizes its lifetime utility, denoted as

$$
\max E_{0} \sum_{t=0}^{\infty} u\left(C_{t}, L_{t}\right),
$$

where $C_{t}$ is consumption of a constant elasticity of substitution basket of differentiated varieties

$$
C_{t}=\left[\int_{0}^{1} C(z)^{\frac{\xi-1}{\xi}} d z\right]^{\frac{\xi}{\xi-1}}
$$

and $L_{t}$ is labor effort. $u$, the period felicity function, takes the following form:

$$
u_{t}=\ln C_{t}-\frac{L_{t}^{\eta+1}}{\eta+1}
$$

where $\eta$ is the inverse of the Frisch elasticity of labor supply. The maximization problem is subject to several constraints. The flow budget constraint, in nominal terms, is the following:

$$
\begin{aligned}
B_{t}+P_{t}^{I} I_{t}+P_{t}^{C} C_{t} & =W_{t} L_{t}+R_{t} K_{t-1}+\left(1+i_{t-1}\right) B_{t-1}+\Delta, \\
I & =\left[\int_{0}^{1} I(z)^{\frac{\xi-1}{\xi}} d z\right]^{\frac{\xi}{\xi-1}} .
\end{aligned}
$$

where

The price indices are defined as follows:

$$
\begin{aligned}
& P_{t}^{C}=\left(\int_{0}^{1} P_{t}^{C}(z)^{1-\xi} d z\right)^{\frac{1}{1-\xi}} \\
& P_{t}^{I}=\left(\int_{0}^{1} P_{t}^{I}(z)^{1-\xi} d z\right)^{\frac{1}{1-\xi}} .
\end{aligned}
$$

Moreover,

$$
\begin{aligned}
& K_{t}=I_{t}+(1-\delta) K_{t-1} \\
& L_{t}=L_{t}^{C}+L_{t}^{I} \\
& K_{t-1}=K_{t}^{C}+K_{t}^{I} .
\end{aligned}
$$

\footnotetext{
${ }^{28}$ The appendix was written primarily by Alessandro Barattieri.
} 
Notice that total capital is predetermined, while sector-specific capital is free to move in each period. To solve the problem, we write the Lagrangian as

$$
\begin{aligned}
& L=\ln C_{t}-\frac{L_{t}^{\eta+1}}{\eta+1}+\ldots-\Lambda_{t}\left(B_{t}+P_{t}^{I} I_{t}+P_{t}^{C} C_{t}-W_{t} L_{t}-R_{t} K_{t-1}-\left(1+i_{t-1}\right) B_{t-1}-\Delta_{t}\right) \\
& -\beta E_{t} \Lambda_{t+1}\left(B_{t+1}+P_{t+1}^{I} I_{t+1}+P_{t+1}^{C} C_{t+1}-W_{t+1} L_{t+1}-R_{t+1} K_{t}-\left(1+i_{t}\right) B_{t}-\Delta_{t+1}\right)-\ldots
\end{aligned}
$$

The first-order conditions of the maximization problem for consumption, nominal bond, labor, and capital are as follows:

$$
\frac{1}{C_{t}}=P_{t}^{C} \Lambda_{t}
$$

$$
\Lambda_{t}=\beta E_{t}\left[\left(1+i_{t}\right) \Lambda_{t+1}\right]
$$

$$
L^{\eta}=\Lambda_{t} w_{t}
$$

$$
\Lambda_{t} P_{t}^{I}=\beta E_{t}\left[\Lambda_{t+1}\left(R_{t+1}+P_{t+1}^{I}(1-\delta)\right)\right] .
$$

Table A1 provides baseline calibrations for all parameters.

\section{Table A1}

\section{Baseline Calibration}

\begin{tabular}{lclc} 
Parameter & Value & Parameter & Value \\
\hline$\beta$ & 0.99 & $I N V_{-} S H A R E$ & 0.2 \\
$\eta$ & 0.25 & $C_{-} S H A R E$ & 0.8 \\
$\alpha_{C}$ & 0.3 & $L^{\prime} / L$ & 0.2 \\
$\alpha_{I}$ & $L^{C} / L$ & 0.8 \\
$\delta$ & 0.3 & $K^{\prime} / K$ & 0.2 \\
$\Gamma^{C}$ & 0.025 & $K^{C} / K$ & 0.8 \\
$\Gamma^{\prime}$ & 1.1 & $\rho_{i}$ & 0.8 \\
$\theta_{C}$ & 1.1 & $\phi_{\pi}$ & 1.5 \\
$\theta_{I}$ & 0.75 & $\phi_{\mu}$ & 0.5 \\
$\zeta_{C}$ & 0.75 & $\rho_{C}$ & 0.99 \\
& $\frac{\left(1-\theta_{C}\right)\left(1-\beta \theta_{C}\right)}{\theta_{C}}$ & $\rho_{I}$ & 0.99 \\
$\zeta_{l}$ & $\left(1-\theta_{I}\right)\left(1-\beta \theta_{I}\right)$ & $\sigma_{\varepsilon_{t}^{c}}$ & 1 \\
& $\theta_{I}$ & $\sigma_{\varepsilon_{t}^{\prime}}$ & 1 \\
\hline
\end{tabular}




\section{Firms}

Both sectors are characterized by a unitary mass of atomistic monopolistically competitive firms. Production functions are Cobb-Douglas (possibly with different factor intensities). Productivity in the two sectors is represented by two AR(1) processes. The cost minimization problem for the firms $z$ operating in the consumption and investment sectors can be expressed, in nominal terms, as

$$
\begin{aligned}
& \operatorname{Min} W_{t} L_{t}^{C}(z)+R_{t} K_{t}^{C}(z) \\
& \text { s.t. } Y_{t}^{C}(z)=A_{t}^{C}\left(K_{t}^{C}(z)\right)^{\alpha^{C}}\left(L_{t}^{C}(z)\right)^{1-\alpha^{C}}-\Phi^{C}
\end{aligned}
$$

and analogously as

$$
\begin{aligned}
& \text { Min } W_{t} L_{t}^{I}(z)+R_{t} K_{t}^{I}(z) \\
& \text { s.t. } I_{t}=A_{t}^{I}\left(K_{t}^{I}(z)\right)^{\alpha^{I}}\left(L_{t}^{I}(z)\right)^{1-\alpha^{I}}-\Phi^{I} .
\end{aligned}
$$

Calling $\mu^{i}$ with $i=C, I$ the multiplier attached to the minimization problem, reflecting nominal marginal cost, we can express the factor demand as follows, where we omit $z$ assuming a symmetric equilibrium:

$$
\begin{aligned}
& \frac{W_{t}}{\mu_{t}^{C}}=(1-\alpha) A_{t}^{C}\left(K_{t}^{C}\right)^{\alpha^{C}}\left(L_{t}^{C}\right)^{-\alpha C} \\
& \frac{R_{t}}{\mu_{t}^{C}}=\alpha A_{t}^{C}\left(K_{t}^{C}\right)^{\alpha^{C}-1}\left(L_{t}^{C}\right)^{1-\alpha} \\
& \frac{W_{t}}{\mu_{t}^{I}}=(1-\alpha) A_{t}^{I}\left(K_{t}^{I}\right)^{\alpha^{I}}\left(L_{t}^{I}\right)^{-\alpha^{I}} \\
& \frac{R_{t}}{\mu_{t}^{I}}=\alpha A_{t}^{I}\left(K_{t}^{I}\right)^{\alpha^{I}-1}\left(L_{t}^{I}\right)^{1-\alpha^{I}} .
\end{aligned}
$$

Taking the ratio for each sector, we get

$$
\begin{aligned}
& \frac{K_{t}^{C}}{L_{t}^{C}}=\frac{\alpha}{1-\alpha} \frac{W_{t}}{R_{t}} \\
& \frac{K_{t}^{I}}{L_{t}^{I}}=\frac{\alpha}{1-\alpha} \frac{W_{t}}{R_{t}} .
\end{aligned}
$$

Inflation rates are naturally defined as

$$
\Pi_{t}^{j}=\frac{P_{t}^{j}}{P_{t-1}^{j}} .
$$

Finally, given the Cobb-Douglas assumption, it is possible to express the nominal marginal cost as follows:

$$
M C^{j}=\frac{1}{A^{j}} \frac{1}{f(\alpha)} R^{\alpha} W^{1-\alpha}\left(Y^{j}+\Phi^{j}\right)
$$

with $j=C, I$. 
We introduce nominal rigidities through standard Calvo (1983) pricing. Instead of writing the rather complex equations for the price levels in the $C$ and $I$ sectors, we jump directly to the log-linearized Calvo equations for the evolution of inflation rates, equations (25) and (26) below.

\section{Monetary Policy}

Monetary policy is conducted through a Taylor-type rule with a smoothing parameter and reaction to inflation and marginal cost. Again, we write the Taylor rule directly in log-linearized form, as equation (A32) below.

\section{Equilibrium}

Beyond the factor market-clearing conditions already expressed, equilibrium also requires a bond market-clearing condition $(B=0)$, a consumption goods market-clearing condition $\left(Y^{C}=C\right)$, and an aggregate adding-up condition $(C+I=Y$ ). (By Walras's law, we drop the investment market-clearing condition.)

\section{The Linearized Model}

The equations of the model linearized around its nonstochastic steady state are represented by equations (A12) through (A36), which are 25 equations for the 25 unknown endogenous variables, $c$, $I^{I}, l^{C}, l, k^{C}, k^{I}, k, \lambda, w, w^{C}, r, i, y^{C}, I, y, p^{I}, p^{C}, \pi, \pi^{C}, \pi^{I}, \mu, \mu^{I}, \mu^{C}, a^{C}, a^{I}$, as follows:

$$
\begin{aligned}
& k_{t}=\delta I_{t}+(1-\delta) k_{t-1} \\
& \frac{L^{I}}{L} l_{t}^{I}+\frac{L^{C}}{L} l_{t}^{C}=l_{t} \\
& \frac{K^{I}}{K} k_{t}^{I}+\frac{K^{C}}{K} k_{t}^{C}=k_{t-1} \\
& -C_{t}=\lambda_{t}+p_{t}^{C}
\end{aligned}
$$

$$
\lambda_{t}=i_{t}+\lambda_{t+1}
$$$$
\eta l=\lambda_{t}+w_{t}
$$$$
\lambda_{t}+p_{t}^{I}=\lambda_{t+1}+[1-\beta(1-\delta)] r_{t+1}+\beta(1-\delta) p_{t+1}^{I}
$$$$
y_{t}^{C}=\Gamma^{C}\left(a_{t}^{C}+\alpha^{C} k_{t}^{C}+\left(1-\alpha^{C}\right) l_{t}^{C}\right)
$$$$
I_{t}=\Gamma^{I}\left(a_{t}^{I}+\alpha^{I} k_{t}^{I}+\left(1-\alpha^{I}\right) l_{t}^{I}\right)
$$$$
k_{t}^{C}+r_{t}=w_{t}+l_{t}^{C}
$$

$$
k_{t}^{I}+r_{t}=w_{t}+l_{t}^{I}
$$


(A23)
$\mu_{t}^{C}=\alpha r_{t}+(1-\alpha) w_{t}-a_{t}^{C}$

$\mu_{t}^{I}=\alpha r_{t}+(1-\alpha) w_{t}-a_{t}^{I}$

$\pi_{t}^{C}=\beta \pi_{t+1}^{C}+\zeta\left(\mu_{t}^{C}-p^{C}\right)$

$\pi_{t}^{I}=\beta \pi_{t+1}^{I}+\zeta\left(\mu_{t}^{I}-p^{I}\right)$

$\pi_{t}^{C}=p_{t}^{C}-p_{t-1}^{C}$

$\pi_{t}^{I}=p_{t}^{C}-p_{t-1}^{I}$

$\mu_{t}=C \_$share $\cdot \mu_{t}^{C}+I N V \_$share $\cdot \mu_{t}^{I}$

$\pi_{t}=C \_$share $\cdot \pi_{t}^{C}+I N V \_$share $\cdot \pi_{t}^{I}$

$w_{t}^{C}=w_{t}-p_{t}^{C}$

$i_{t}=\rho_{i} i_{t-1}+\left(1-\rho_{i}\right)\left(\phi_{\pi} \pi_{t}+\phi_{\mu} \mu_{t}\right)$

$y_{t}=C \_$share $\cdot C_{t}+I N V \_$share $\cdot I_{t}$

$y_{t}^{C}=C_{t}$

$a_{t}^{C}=\rho_{C} a_{t-1}^{C}+\varepsilon_{t}^{C}$

$a_{t}^{I}=\rho_{I} a_{t-1}^{I}+\varepsilon_{t}^{I}$. 
